\title{
Impact of Strategic Agility Determinants and Dimensions on Institutional Performance Excellence in Government Institutions in the Hashemite Kingdom of Jordan
}

\author{
Atallah Mohammed Tayser Alsharah ${ }^{1}$ \\ ${ }^{1}$ Business Administration Department, Imam Muhammad Ibn Sau'd Islamic University, Riyadh, KSA \\ Correspondence: Atallah Mohammed Tayser Alsharah, Associate Professor, Business Administration Department, \\ Imam Muhammad Ibn Sau'd Islamic University, Riyadh, KSA.
}

Received: July 3, 2020

Accepted: August 17, 2020

Online Published: September 6, 2020

doi:10.5430/ijba.v11n5p29

URL: https://doi.org/10.5430/ijba.v11n5p29

\begin{abstract}
This study aims at investigating the impact of Strategic Agility Determinants and Dimensions on Organizational Performance Excellence in Government Organizations in the Hashemite Kingdom of Jordan. The study population consisted of all department heads or their representatives in Jordanian government organizations and departments affiliated to Prime Ministry according to the approved organizational structure of the state amounting 30 organization and department. Due to population large size, a random sample from these originations was selected. 252 questionnaires were distributed. 226 questionnaires were recollected so the response rate is $(89.7 \%)$.

The study concluded a set of results: the most important is that there is a statistically significant impact of strategic agility determinants and dimensions of (strategic sensitivity, strategic goals selection, and clarity of vision, shared responsibility, core capabilities, and collective commitment) on organizational performance excellence in Jordanian government organizations, The results showed that Jordanian government organizations have clear vision and mission for their future activities and they have clear goals known by all employees to achieve vision and mission. It was found that there is an integration and harmony in setting goals and work procedures among various Jordanian government organizations. The results also showed that Jordanian government organizations do not care much regarding involvement of their employees in strategic planning process, nor are they keen to discuss differentiated ideas and do not encourage creativity and provide suggestions by organizations employees in these. Also the top management in government organizations does not focus heavily on team working in one team spirit, nor does maintain their skilled employees.

Finally, the study recommended a set of recommendations, the most important of which is the Jordanian government organizations have to increase their interest in all strategic agility dimensions and determinants due to their great role in achieving organizational performance excellence. And Government organizations should seek to achieve organizational excellence to increase interest in involving their employees in strategic planning process, discuss distinguished ideas, and encourage creativity and submitting proposals by their employees. Also, Team working with one team spirit is main pillar of organizational excellence, therefore it is necessary to increase interesting to and focus on this topic by top management in Jordanian organizations.
\end{abstract}

Keywords: strategic agility, organizational performance excellence, government organizations

\section{Introduction}

Organizations seek to achieve Institutional Performance excellence through having capabilities and resources by which they can face rapid changes in external environment. Strategic agility is one of the most important capabilities that help organizations to respond to these changing and rapid situations, through clear vision, good selection of strategic goals and shared responsibility. So, this study aims to investigate the impact of strategic agility determinants and dimensions impact on an important element that public and private sector organizations seek to have, namely: institutional performance excellence. 


\section{Study Problem}

Jordanian government institutions have a major role in achieving social welfare and improving services provided to citizens. Therefore, attention was paid to this study topic to measure strategic agility determinants and dimensions impact on institutional performance excellence due to its significant role in development and improvement services provided by such institutions to citizens. The study was applied on a group of government institutions whose success or failure has a very significant impact on Jordan and Jordanian citizens. To identify the study problem accurately, an exploratory study was conducted on 15 officials in these institutions to find out their perspectives on this study research issue., It was concluded by answering questionnaire statements that there is a strongly agreement on strategic agility dimensions importance and its great role in achieving institutional excellence in these institutions.

\section{Study Significance}

The study significance emerged through its attempt to bridge the lack of research related to strategic agility concepts for Jordanian government institutions employees and achieving institutional performance excellence, where strategic agility is a key approach to achieve strategic flexibility that organizations need in general to face internal and external changes. Consequently, the flexibility and agility of these organizations is believed to help improvement of overall job performance and achieve organizational performance excellence in these institutions.

The importance of this study also stems from the fact that it will open new horizons for research fields in strategic agility concept of connect it with institutional performance excellence in other sectors, the study results and its recommendations will contribute in providing some information to decision makers and thus help them in taking appropriate procedures.

\section{Research Model}

Independent Variable

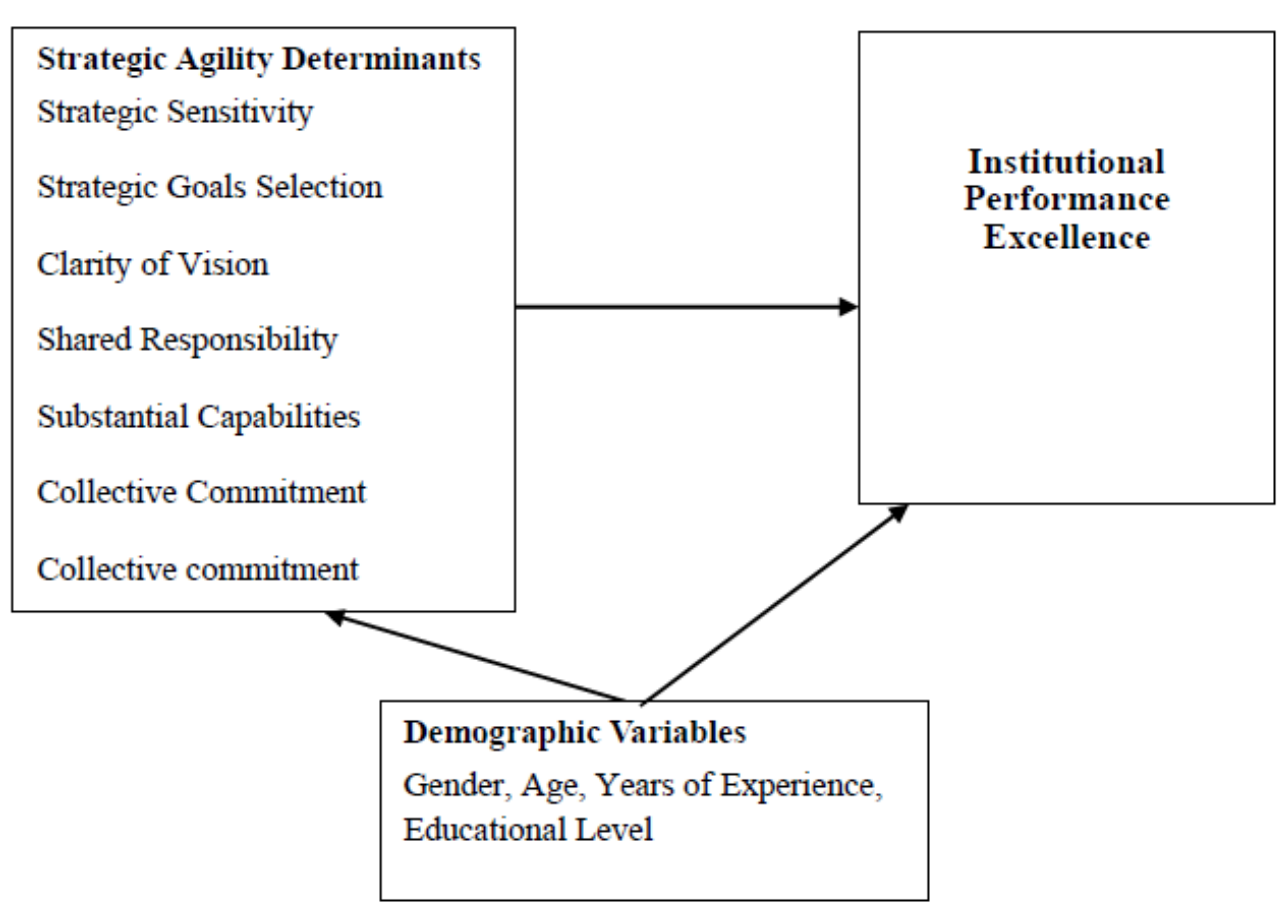

\section{Hypotheses of the Study}

The hypotheses of the current study are as follows:

A. The first main hypothesis: There is a statistically significant impact of strategic agility (strategic sensitivity, selecting strategic goals, clarity of vision, shared responsibility, Substantial Capabilities, Collective Commitment) determinants and dimensions on institutional performance excellence in Jordanian government institutions. 
The following sub-hypotheses were derived:

The first sub-hypothesis: There is a statistically significant impact of strategic sensitivity dimension on institutional performance excellence in Jordanian government institutions.

The second sub-hypothesis: There is a statistically significant impact of selecting strategic goals dimension on institutional performance excellence in Jordanian government institutions.

Third Sub Hypothesis: There is a statistically significant impact of clarity of vision dimension on institutional performance excellence in Jordanian government institutions.

Fourth sub-hypothesis: There is a statistically significant impact of shared responsibility dimension on institutional performance excellence in Jordanian government institutions.

Fifth sub-hypothesis: There is a statistically significant impact of Substantial Capabilities dimension on institutional performance excellence in Jordanian government institutions.

Sixth Sub Hypothesis: There is a statistically significant impact of Collective Commitment dimension on institutional performance excellence in Jordanian government institution.

B. The second main hypothesis: There are statistically significant differences between the means of respondents' responses regarding strategic agility practicing due to demographic variables (gender, age, years of experience, educational level).

C.The third main hypothesis: There are statistically significant differences between the means of respondents' responses regarding institutional performance excellence due to demographic variables (gender, age, years of experience, educational. level).

\section{Study Objectives}

The study aims to:

A. Highlighting strategic agility concept is a new concept and provide theoretical framework showing concept relationship with institutional performance excellence.

B. To identify strategic agility determinants and dimensions availability in Jordanian government institutions.

C. To find out institutional performance excellence level in Jordanian government institutions.

D. To identify strategic agility determinants and dimensions impact on institutional performance excellence in Jordanian government institutions.

E. Providing recommendations and suggestions that help decision-makers in study topic.

\section{Limitations}

The study was limited to Jordanian governmental institutions and departments. It was conducted as of 1/6/2019 up to $15 / 4 / 2020$.

\section{Population and Sampling}

The study population includes all department heads or their representatives in Jordanian government institutions and departments affiliated to the Prime Minister according to the approved organizational structure of the state amounting 30 institution and department. Due to population large size and in order to select a representative sample, a random sample from this institution was used. 252 questionnaires were distributed. 226 questionnaires were recollected so the response rate was $(89.7 \%)$.

\section{Literature Review}

\section{First: strategic agility.}

\section{A. Strategic agility concept}

Strategic agility concept is considered as one of features that differentiate new organizations due to their ability to adapt and continuous flexibility in their work. Doze \& Coonan defined it as "the ability to continuously adapt to strategic orientation in business as a function of strategic functions and strive to create not only new products and services but also new business models and innovative ways of creating value (Aurdan, 2011). Harizat (2015) referred to it as "organization's ability to adapt to strategic changes that affect its business." Al-Sanea (2013) defined it as "the art of leading organization's ability in a rapidly changing business environment." Idris. \& Al-Rubiae (2013) also 
defined it as "perfection in change by adopting the concept of agility in organization to enhance points and providing the organization with what is necessary for its survival."

The researcher defines it as "the ability that organization seeks to have and prepare through it to make certain strategic changes that aimed at achieving an appropriate response for accelerating environmental events".

\section{B. Strategic agility importance}

Mustafa, (2010), Ojha, (2008), Al-Kubaisi and Nuri, (2013), Ruth, (2008), Haniyeh, (2016), and Al-Zabin, (2013) indicated organizations need importance of strategic agility as follows:

- Strategic agility has significant importance in organizations survival because it is a way to manage unexpected changes and risks organization face.

-Increasing organization's competitiveness, therefore it is a mean of excellence and superiority over competitors.

-It is a mean to capture appropriate opportunities and to take advantage in turbulent world.

- Creative and innovative business performance as a result of rapid response to changes in the external environment

\section{Strategic agility dimensions}

This study used the most common of strategic agility dimensions, namely:

- Strategic sensitivity, it is the awareness of organization's strategic orientation and its perception of the method by which it can achieve its vision, mission and strategic goals through utilizing opportunities and speed in dealing with competitors. (Al-Badrani,2015),( Radwan ,2014)

- Strategic Goals Selection: Organization's selection related to its strategic goals enhances its ability to modify, and develop its capabilities to take available opportunities advantage., Goals consider strategic orientation, ambitious and challenging are for achieving excellence and organization entrepreneurship.

- Clarity of Vision: Vision is what organization aspires to achieve and create in future. Therefore, achieving this vision requires developments and changes follow-up in the external environment; consequently, clarity of vision requires the existence of a set of standard principles that guide organization's work for the purpose of making its differentiated work performance. Such principles and standards provide the needed guidance that must be maintained in future conception. (Musaada, 2013), (Al-Ghalbi, Idris, 2007), (Abu Rady, 2013)

- Shared responsibility: organization's shared responsibility must be based on subordinate's high degree confidence through, the existence of effective communication systems, and participation of all in improving work methods and evaluating the results.

- Substantial Capabilities: They refer to the unique features and resources that organization has as a result of accumulated organizational learning in organization. Which consequently lead to actual professionalism in internal activities performance (Mohamed, 2012)? Organization's substantial capabilities enhance required speed and stability to achieve strategic agility. Therefore, this will help organization to take advantage of available opportunities that achieve its goals and differentiate them from competing organizations.

- Collective Commitment: it represents individuals 'loyalty and adherence to organization and its goals and values. This helps organization to speed up, creativity and differentiate in drafting decisions and thus excellence in achieving its goals.

\section{Advantages of agile organization}

Agile organizations are characterized by flexibility, fighting inertia, independence, decentralization, and faraway from control. These organizations are also differentiated by their coping with conditions through integration of information technology, individuals and processes within a flexible organization capable of rapid response to environmental events and changes (Apache, 2012, Aurdan), 2011).

\section{Second: Institutional Performance Excellence}

\section{A. Institutional performance excellence concept}

Institutional performance excellence is considered as one of new managerial concepts, where organizations strive to provide their services and products in an innovative and creative manner so that they can compete, Al-Rubaie, (2015) defined it as a group of rare and unique organizational characteristics that organization enjoys compared to competing organizations. This consequently makes it able to manage its resources and enhance its competitive 
position. Thus, excellence in institutional performance is considered one creativity approaches and makes the organization able to respond quickly to environmental changes and thus outperform its competitors.

\section{B. Perquisites for achieving institutional performance excellence}

Among the most important perquisite for achieving institutional performance excellence is:

1- Understand the style, management philosophy, and faraway from bureaucracy

2-Planning through work teams and considering employees as partners

3-Focus on employee's comprehensive training and development

4- Linking incentives to performance

5- Motivating employees to take responsibility and accept responsibility. (Hassan, 2015, Al-Fatlawi, 2012, Al-Nsour, 2010).

C. Obstacles of achieving differentiated performance in جThere are many obstacles of achieving differentiated performance in organizations. Researcher believes that the existence of traditional leadership style is one of the most important of these obstacles, in addition to a set of other factors such as weak creativity culture, lack of focus on long-term strategy, and lack of awareness of customer requirements.

\section{Previous Studies}

Several studies have addressed strategic agility topic connect it with multiple variables. Among such studies the following:

Al-Hawajrah and Al-Azab, (2019) study aimed to measure and analyses workforce diversity impact in achieving strategic agility in United Nations organizations working in Jordan. The study concluded that there is an effect of workforce, diversity with its various dimensions, on strategic agility., Al-Azzawi and Al-Dabbagh, (2019) aimed to investigate the relationship between organizational agility and service quality. The researcher concluded that studied companies neglect changes in external environment.

Abdul Razzaq, (2018) study aimed to know the relationship between leadership styles in Iraqi organizations and strategic agility determinants (strategic sensitivity, collective commitment, resources liquidity). Study results showed that there is a relationship between leadership styles (democratic and Laissez-Faire style) and strategic agility. Ismail, (2018) study aimed investigate the strategic agility role in improving decisions quality $\mathrm{n}$ Palestinian NGOs. The study concluded that there is an impact of strategic agility dimensions on improving decisions quality. Amro and Heba, (2016) addressed the relationship between strategic agility and competitive advantage in telecommunications companies operating in Palestine. The study concluded that there is a direct relation between strategic agility and competitive advantage. Finally, Idris \& Alrubie (2013) aimed to investigate strategic learning impact on strategic agility in Elba House in Jordan. The study concluded that there is an impact of strategic learning on strategic agility the study recommended the importance of enhancing learning dimensions due to its vital role in promoting strategic agility.

All previous studies provided valuable and important recommendations for studied parties. They may have a significant impact in changing work mechanisms, but this study has advantages from previous studies, it tries to investigate the relationship between new strategic agility determinants and dimensions, namely (strategic sensitivity, strategic goals selection, clarity of vision, Shared responsibility, fundamental changes, and collective commitment) with an important variable that has a major role in providing differentiated service to Jordanian citizen, which is institutional performance excellence, which was not studied before. This research was conducted on a set of important Jordanian government institutions, which were not previously discussed in this matter, which are the institutions affiliated to the prime ministry in Jordan. The researcher expects that there will be an impact of these study recommendations in improving work mechanisms in these institutions in the future. The researcher hopes that more research will be conducted to address strategic agility topic and its limitations in this study and explain its relationship with institutional excellence in ministries, institutions and other Jordanian companies.

\section{Data Analysis}

\subsection{Study's Sample Characteristics}

The following tables show the most important results of collected data analysis from study sample: 
Table 1. Sample distribution

\begin{tabular}{lll}
\hline Gender & Frequency & Percentage\% \\
\hline male & 137 & 60.6 \\
\hline female & 89 & $39 . .4$ \\
\hline Total & 226 & 100 \\
\hline Age & Frequency & Percentage\% \\
\hline Less than 30 & 3 & 1.3 \\
\hline 31 - 40 years & 108 & 47.8 \\
\hline 41-50 years & 102 & 45.1 \\
\hline More than 50 years & 13 & 5.8 \\
\hline Total & 226 & 100 \\
\hline Educational Level & Frequency & Percentage\% \\
\hline high school & 4 & 1.8 \\
\hline diploma & 11 & 4.8 \\
\hline bachelor's degree & 186 & 82.3 \\
\hline master's degree & 25 & 11.1 \\
\hline Total & 226 & 100 \\
\hline Experience & Frequency & Percentage\% \\
\hline Less than 5 years & 6 & 2.6 \\
\hline 5-10 years & 72 & 31.9 \\
\hline 11-20 years & 117 & 51.8 \\
\hline More than 20 years & 31 & 13.7 \\
\hline Total & 226 & 100 \\
\hline
\end{tabular}

Table 1 indicates that males' percent in study sample was $60.6 \%$ of the total study sample, while female percent was39.4\%. Males' high percent in the sample is due to increase number of male staffs. Sample distribution according to Age results indicates that $47.8 \%$ of study sample, are of age group (31-40) years, and it is the highest percent of the total study sample. while the age group (41-50) years ranked the second with $45.1 \%$ of the total sample, $5.8 \%$ of the total sample are of the age group More than 50 years, Age group less than 30 years ranked the last with $1.3 \%$ of the total sample. Sample distribution according to educational level results indicate $82.3 \%$, of sample is concentrated in those who have bachelor's degree, while $11.1 \%$ of the total sample have master degree, those who have diploma degree ranked the third with $4.8 \%$ of the total sample, while high secondary school degree ranked the last with $1.8 \%$ of the total sample. Sample distribution by years of experience results indicates that study sample is concentrated on those who have experience $11-20$ years with $51.8 \%$ of the total sample, those who have 5-10 years' experience ranked the second amounting $31.9 \%$ of the total sample, while the percent of those who have experience More than 20 years with $13.7 \%$ of total sample, Finally employees whom their experience less than five years amounting $2.6 \%$.

\subsection{Questionnaire Statements Analysis}

a. Independent variable statements analysis (strategic sensitivity) 
Table 2. Summery of first dimension (strategic sensitivity) results

\begin{tabular}{lllll}
\hline No. & Statement & Mean & S.D & R. Weight $\%$ \\
\hline 1 & The organization has clear vision for future activities & 4.54 & 0.84 & 90.8 \\
\hline 2 & Organization goals and mission are clear and known for all employees & 4.29 & 0.72 & 85.8 \\
\hline 3 & The organization has strategic and operational plans for all projects & 4.23 & 0.71 & 84.6 \\
\hline 4 & The organization has clear mechanisms and methods to face challenges & 3.98 & 0.81 & 79.6 \\
\hline 5 & The organization is flexible in redistributing and utilizing resources & 3.96 & 0.73 & 79.3 \\
\hline 6 & $\begin{array}{l}\text { The organization focuses on continuous improvement in its work } \\
\text { performance }\end{array}$ & 4.62 & 0.69 & 92.5 \\
\hline 7 & The organization involves employees in strategic planning process & 3.02 & .071 & 61.04 \\
\hline 8 & $\begin{array}{l}\text { The organization has technological techniques that help in enhancing } \\
\text { organization strategic agility }\end{array}$ & 4.01 & 0.75 & 80.2 \\
\hline 9 & The organization has new methods for business performance & 4.04 & 0.72 & 80.8 \\
\hline 10 & The organization is constantly keen to discuss differentiated ideas & 3.17 & .074 & 63.4 \\
\hline 11 & $\begin{array}{l}\text { Organization's leaders are differentiated by their initiatives and having } \\
\text { organized thinking }\end{array}$ & 3.64 & 0.67 & 72.8 \\
\hline 12 & The organization learns from past experiences and avoids mistakes & 3.98 & 0.74 & 79.6 \\
\hline
\end{tabular}

Table 2 indicates that the sixth statement ranked the first in strategic sensitivity dimension. This means that there is a high agreement of study sample subjects that Jordanian government organizations focus on continuous improvement in their work performance. Table also indicates, that there is a high agreement regarding statements $(1,2,3)$. This indicates that Jordanian government organizations have clear vision regarding their future activities, in addition their goals and mission are clear and known to employees. They also have strategic and operational plans for all projects. Table also shows that statement seven ranked the last, which indicates that Jordanian government organizations do not pay high attention to their employee's involvement in strategic planning process, nor are they keen to discuss employee's differentiated ideas.

Table 3. Summary of Second dimension (strategic goals selection) results

\begin{tabular}{|c|c|c|c|c|}
\hline No. & Statement & Mean & S.D & R. Weight $\%$ \\
\hline 1 & $\begin{array}{l}\text { The organization has full flexibility in performing its goals that } \\
\text { are appropriate to changes in work environment }\end{array}$ & 4.21 & 0.71 & 84.2 \\
\hline 2 & Goals that achieve organization's vision and mission are placed & 4.65 & 0.82 & 93 \\
\hline 3 & Organization's goals are clear to all and are measurable & 4.38 & .076 & 87.6 \\
\hline 4 & $\begin{array}{l}\text { Organization's goals are associated with country's overall strategic } \\
\text { plan. }\end{array}$ & 4.43 & 0.83 & 88.6 \\
\hline 5 & $\begin{array}{l}\text { There is integration between organization's goals and other } \\
\text { departments and organizations goals. }\end{array}$ & 4.35 & 0.78 & 87 \\
\hline 6 & $\begin{array}{l}\text { Work procedures are clear to all employees and perform the } \\
\text { previous placed goals. }\end{array}$ & 4.26 & .072 & 85.2 \\
\hline 7 & $\begin{array}{l}\text { Change in goals process is associated to new development } \\
\text { projects and new available opportunities. }\end{array}$ & 4.23 & 0.69 & 84.6 \\
\hline 8 & New technological means are used to perform organization goals & 4.16 & 0.75 & 83.2 \\
\hline
\end{tabular}


Table 3 shows that all second dimension (strategic goals selection) statements have high agreement, this indicates that Jordanian government organizations set goals that achieve their vision and mission, and that their goals are clear to all, measurable and associated with state strategic plan.

Table 4. Summary of third dimension (Clarity of Vision) results

\begin{tabular}{lllll}
\hline No. & Statement & Mean & S.D & R. Weight \% \\
\hline 1 & $\begin{array}{l}\text { The organization has clear vision regarding their future it wants to } \\
\text { be }\end{array}$ & 4.51 & 0.80 & 90.2 \\
\hline 2 & Organization's vision is achieved realistically & 4.24 & 0.71 & 84.8 \\
\hline 3 & $\begin{array}{l}\text { Organization's vision and values are clear to all organization } \\
\text { employees }\end{array}$ & 4.55 & 0.79 & 91 \\
\hline 4 & $\begin{array}{l}\text { There is an integration and harmony between organization's units } \\
\text { and divisions to achieve organization's vision. }\end{array}$ & 4.38 & 0.71 & 87.6 \\
\hline 5 & $\begin{array}{l}\text { Organization's goals and development plans are in line with } \\
\text { organization's vision }\end{array}$ & 4.12 & 0.68 & 82.4 \\
\hline 6 & $\begin{array}{l}\text { There is an integration and harmony between organization other } \\
\text { government organizations in the country }\end{array}$ & 0.44 & 0.78 & 88.8
\end{tabular}

Table 4 shows that sample subjects' responses means are high for all second-dimension statements (clarity of vision), this indicates that Jordanian government organizations have clear vision regarding the future they want, in addition their vision and values are clear to all employees.

Table 5. Summary of fourth dimension (shared responsibility) results

\begin{tabular}{|c|c|c|c|c|}
\hline No. & Statement & Mean & S.D & R. Weight $\%$ \\
\hline 1 & $\begin{array}{l}\text { The Organization encourages shared responsibility with all parties } \\
\text { it deals with }\end{array}$ & 3.19 & 0.70 & 63.8 \\
\hline 2 & The Organization involves its employees in the planning process & 2.97 & 0.68 & 59.4 \\
\hline 3 & $\begin{array}{l}\text { The Organization encourages its employees to be creative and to } \\
\text { make suggestions }\end{array}$ & 2.95 & 0.71 & 59 \\
\hline 4 & $\begin{array}{l}\text { The Organization facilitates information access to its services } \\
\text { beneficiaries }\end{array}$ & 3.56 & 0.72 & 71.2 \\
\hline 5 & $\begin{array}{l}\text { The information in the organization is clear and available to all } \\
\text { employees }\end{array}$ & 3.74 & 0.69 & 74.8 \\
\hline 6 & $\begin{array}{l}\text { The Organization considers its employees mistakes as an } \\
\text { opportunity to learn and improve the work }\end{array}$ & 3.42 & 0.74 & 68.4 \\
\hline 7 & The organizations treat all stakeholders as liability partners & 3.02 & 0.73 & 60.4 \\
\hline
\end{tabular}

Table 5 indicates that the majority of the fourth dimension (Shared Responsibly) statements means are medium. The table indicates that Jordan governmental organizations interest is more than medium. Table also shows that sample organization interest is medium in providing all employees and its services benefices Table also indicates that Jordan governmental organizations interest in encouraging shared responsibility principal with all parties is medium.

Statements $(2,3)$ mean are low and below the medium, this indicates that Jordanian government organizations do not pay high attention in involving their employees' strategic planning process, nor they encourage they employees to be creative and to present suggestion from their punt of view. 
Table 6. Summary of Fifth dimension (substantial abilities) results

\begin{tabular}{lllll}
\hline No. & Statement & Mean & S.D & R. Weight \% \\
\hline 1 & The organization has good reputation in the society & 3.65 & 0.76 & 73 \\
\hline 2 & The Organization provides its services quickly and efficiently & 3.32 & 0.70 & 66.4 \\
\hline 3 & $\begin{array}{l}\text { The Organization has modern and advanced methods in providing } \\
\text { its services }\end{array}$ & 3.54 & 0.74 & 70.8 \\
\hline 4 & $\begin{array}{l}\text { Organization's employees have the necessary skills to provide } \\
\text { services to beneficiaries }\end{array}$ & 4.22 & 0.78 & 84.4 \\
\hline 5 & $\begin{array}{l}\text { The Organization retains its efficient and skilled employees } \\
\text { The organization has the resources it needs to perform its various } \\
\text { operations }\end{array}$ & 2.96 & 0.68 & 59.4 \\
\hline
\end{tabular}

Table 6 indicates that Jordanian government organizations do not retain their efficient and skilled employees, nor do they have resources they need to perform their various operations from sample point of view as stated in statement nose $(5,6)$, Table also indicated that The fourth statement ranked the first in this dimension, This indicates that Jordanian government organizations employees have the needed skills to provide services to beneficiaries, while the rest statements are within the mean in study sample responses.

Table 7. Summary of sixth dimension (collective commitment) results

\begin{tabular}{lllll}
\hline No. & Statement & Mean & S.D & R. Weight $\%$ \\
\hline 1 & The organization enhances its own organizational culture & 3.56 & 0.71 & 71.2 \\
\hline 2 & Top management focuses on encouraging team working & 2.74 & 0.72 & 54.8 \\
\hline 3 & Employees are obligated to work many years for the organization & 3.76 & 0.69 & 75.2 \\
\hline 4 & $\begin{array}{l}\text { The public interest is more important than employees' personal } \\
\text { interest }\end{array}$ & 4.02 & 0.74 & 80.4 \\
\hline 5 & Employees are loyal and belonging to organization & 4.29 & 0.73 & 85.8 \\
\hline 6 & Punishment and reward methods are clear to all employees & 3.83 & 0.71 & 76.6 \\
\hline 7 & All employees work with one team spirit & 2.92 & 0.72 & 58.4 \\
\hline
\end{tabular}

Table 7 indicates that statements nos. 5 and 4 ranked first and second respectively this indicates that employees are loyal and belonging to organization they work with. They also prefer public interest over personal interest. The rest statement was around the mean, save statements $(2,7)$, were below the mean. This indicates that Jordanian government organizations do not focus heavily on team working.

B. Organizational performance excellence statements analysis

Table 8. Summary of dependent variable (organizational performance excellence) results

\begin{tabular}{|c|c|c|c|c|}
\hline No. & Statement & Mean & S.D & R. Weight $\%$ \\
\hline 1 & $\begin{array}{l}\text { The organization seeks to obtain government Excellence } \\
\text { Awards }\end{array}$ & 4.76 & 0.84 & 95.2 \\
\hline 2 & $\begin{array}{l}\text { The organization has a special department or section for } \\
\text { excellence }\end{array}$ & 4.26 & 0.72 & 85.2 \\
\hline 3 & $\begin{array}{l}\text { The Organization seeks to achieve international standards in } \\
\text { performance excellence }\end{array}$ & 4.21 & 0.71 & 84.2 \\
\hline 4 & $\begin{array}{l}\text { The Organization approves scientific research methods to solve its } \\
\text { problems }\end{array}$ & 4.17 & 0.81 & 83.4 \\
\hline
\end{tabular}




\begin{tabular}{|c|c|c|c|c|}
\hline 5 & The Organization pays attention to its service benefices opinions & 2.92 & 0.73 & 58.4 \\
\hline 6 & The organization provides beneficiaries with services on time & 4.30 & 0.69 & 86 \\
\hline 7 & $\begin{array}{l}\text { The organization has methods and means to receive beneficiaries' } \\
\text { complaints }\end{array}$ & 4.32 & 0.71 & 86.4 \\
\hline 8 & $\begin{array}{l}\text { The Organization improves and develops continuously its internal } \\
\text { business according to ideal methods }\end{array}$ & 4.07 & 0.75 & 81.4 \\
\hline 9 & The organization retains its differentiated employees & 2.54 & 0.72 & 50.8 \\
\hline 10 & $\begin{array}{l}\text { Incentives and bonuses are distributed fairly to differentiated } \\
\text { employees }\end{array}$ & 2.65 & 0.74 & 53 \\
\hline 11 & The Organization improves employee's income level & 1.24 & 0.67 & 24.8 \\
\hline 12 & The Organization continuously improves working environment & 4.51 & 0.74 & 90.2 \\
\hline 13 & $\begin{array}{l}\text { Employees are evaluated according to clear and fair manners and } \\
\text { methods }\end{array}$ & 4.02 & 0.69 & 80.4 \\
\hline 14 & $\begin{array}{l}\text { The Organization provides employees with appropriate training } \\
\text { and education }\end{array}$ & 4.23 & 0.71 & 84.6 \\
\hline 15 & $\begin{array}{l}\text { Employee's appointment in the organization is according to clear } \\
\text { and fair methods }\end{array}$ & 2.76 & 0.75 & 55.2 \\
\hline
\end{tabular}

Table 8 shows study sample opinions regarding the dependent variable (organizational Performance excellence) that statements no's $(12,1)$ ranked first and second respectively. This indicates that Jordanian government organizations seek to obtain government excellence awards. The researcher believes that the reason behind this interest is the existing of many awards at state level that encourage obtaining excellence awards, in addition, these organizations are interested with continuous improvement of work environment. Table also indicates that study sample responses mean for statements $(3,4,8,13,7,6,2,14)$ is high. This indicates Jordanian government organizations interest in these aspects, regarding the existence of means and methods in Jordanian government organizations to receive beneficiaries' complaints, and to provide beneficiaries services of their work timely in particular. While study sample responses for statements nos. $(11,9,10,15,5)$ were below level, which means that Jordanian government organizations do not seek to improve their employees income level ., this may be due to salaries scale in such organization is linked to specific salaries scale on state level as a whole These organizations also do not seek to maintain their differentiated employees, nor incentives and bonuses are fairly distributed., Sample's subjects responses mean indicate that these organizations do not follow clear and fair methods in employees appointing, and they do not take in consideration beneficiaries.

\section{Hypotheses Testing}

The first main hypothesis: There is a statistically significant impact of strategic agility (strategic sensitivity, selecting strategic goals, clarity of vision, shared responsibility, Substantial Capabilities, Collective Commitment) determinants and dimensions on institutional performance excellence in Jordanian government institutions.

to identify the impact of independent variable (strategic agility dimensions) on dependent variable (organizational performance excellence), multiple linear regression analysis was used. Table (9) shows multiple linear regression analysis Results.

Table 9. Multiple Linear Regression Model to measure determinants and dimensions of strategic agility impact on organizational performance

\begin{tabular}{|c|c|c|c|c|c|c|c|}
\hline $\begin{array}{l}\text { Strategic } \\
\text { Determination }\end{array}$ & B & T-test & Sig. & Ranking & F.test & Sig. & R2 \\
\hline Strategic Sensitivity & 0.216 & 5.182 & & 3 & & & \\
\hline Strategic goals Selection & 0.321 & 5.424 & & 2 & & & \\
\hline Clarity of Vision & 0.368 & 3.251 & & 1 & & & \\
\hline
\end{tabular}




\begin{tabular}{|c|c|c|c|c|c|c|c|}
\hline Shared Responsibility & 0.176 & 2.452 & \multirow[t]{3}{*}{0.000} & 5 & \multirow[t]{3}{*}{85.23} & \multirow[t]{3}{*}{0.000} & \multirow[t]{3}{*}{0.911} \\
\hline Substantial Capabilities & 0.123 & 2.183 & & 6 & & & \\
\hline Collective Commitment & 0.192 & 2.862 & & 4 & & & \\
\hline
\end{tabular}

Table 9 indicates that determination coefficient value is high, amounting (0.911), this means that strategic agility dimensions and determinants value interprets a large percentage of change in organizational performance excellence .Table also indicates that the second dimension (clarity of vision) ranked the first in terms of impact on organizational performance excellence, the impact was (0.368), This means that improving clarity of vision in one degree, will contribute to improve organizational performance excellence wit (0.368), in light other independent variables impact are fixed.

Strategic goals selection, strategic sensitivity, collective commitment, shared responsibility, core capabilities ranked the second, third, fourth, fifth and sixth respectively in affecting organizational performance excellence, the impact size was $(0.321,0.216,0.192,0.176,0.123)$ respectively.

Therefore, the study concluded the validity of the first main hypothesis, which state Six sub-hypotheses have been derived, where each determinant of strategic agility determinants has been investigated and its impact on organizational performance excellence through simple and multiple regression tests. Table no. (10) Shows first main hypothesis and the sub-hypotheses testing results find out the impact of independent variable (strategic agility) on the dependent variable (organizational performance excellence).

Table 10. Simple linear regression results of strategic agility dimensions impact on organizational performance excellence

\begin{tabular}{llllll}
\hline Strategic Agility Determination & $\mathrm{B}$ & $\mathrm{R}$ & $\mathrm{R} 2$ & $\mathrm{~F}$ & Sig \\
\hline Strategic Sensitivity & 0.886 & 0.865 & 0.648 & 341.61 & 0.000 \\
\hline Strategic goals Selection & 0.812 & 0.798 & 0.589 & 298.94 & 0.000 \\
\hline Clarity of Vision & 0.897 & 0.891 & 0.693 & 421.04 & 0.000 \\
\hline Shared Responsibility & 0.728 & 0.704 & 0.513 & 296.32 & 0.000 \\
\hline Substantial Capabilities & 0.785 & 0.738 & 0.610 & 294.18 & 0.000 \\
\hline Collective Commitment & 0.778 & 0.759 & 0.602 & 253.87 & 0.000 \\
\hline
\end{tabular}

Table shows that there is a direct correlation between of strategic agility determinants (according to table above) and organizational performance excellence, since the correlation coefficient between the two variables was $(0.865,0.798$, 0.891, 0.704, 0.738, and 0.759) Simple linear regression results show that there is a positive impact of strategic agility determinants ( according to table above) on organizational performance excellence, since regression coefficient was $(0.778,0.785,0.728,0.897,0.812,0.886)$. This means that increase in each determinant level of strategic agility determinants by one degree will lead to an increase in organizational performance excellence respectively, against this determinant by $(0.886,0.812,0.897,0.728,0.785$, and 0.778$)$. As for determination coefficient for the regression model was $(0.648,0.589,0.693,0.513,0.610,0.602)$, and this means that strategic fitness determinants (according to table above) interpret $(0.648,0.589,0.693,0.513,0.610,0.602)$ of Organizational performance excellence variation. It is also observed that significance level (F-Test) was (0.000) .The values are less than significance level (0.05). This indicates that the result is significant for of strategic agility determinants at this level. Consequently, these results confirm the validity of all sub- hypotheses of the first main hypothesis

Second Main Hypothesis: There are statistically significant differences between the means of respondents' responses regarding strategic agility practicing due to demographic variables (gender, age, years of experience, educational level).

To verify this hypothesis, t test was used for the two independent samples to test the differences due to gender variable, One Way Anova analysis was used to test the differences due to other variables that consist of more than two groups Table no. (11) Results of testing sample's subjects' responses differences regarding strategic agility due to demographic variables. 
Table 11. Shows the second main hypothesis test according to demographic variables

\begin{tabular}{|c|c|c|c|c|}
\hline demographic variables & Mean & S.D & T-test & Sig. \\
\hline \multicolumn{5}{|l|}{ Gender } \\
\hline male & 4.16 & 0.57 & \multirow[t]{2}{*}{$\mathrm{T}=0.495$} & \multirow[t]{2}{*}{0.569} \\
\hline female & 4.11 & 0.48 & & \\
\hline \multicolumn{5}{|l|}{ Age } \\
\hline Less than 30 & 4.24 & 0.53 & \multirow[t]{4}{*}{$\mathrm{F}=1.38$} & \multirow[t]{4}{*}{0.296} \\
\hline $31-40$ years & 4.22 & 0.46 & & \\
\hline $41-50$ years & 4.11 & 0.51 & & \\
\hline More than 50 years & 4.02 & 0.48 & & \\
\hline \multicolumn{5}{|l|}{ Educational Level } \\
\hline high school & 4.02 & 0.41 & \multirow[t]{4}{*}{$\mathrm{F}=0.32$} & \multirow[t]{4}{*}{0.792} \\
\hline diploma & 4.06 & 0.49 & & \\
\hline bachelor's degree & 4.19 & 0.56 & & \\
\hline master's degree & 4.13 & 0.53 & & \\
\hline \multicolumn{5}{|l|}{ Experience } \\
\hline Less than 5 years & 4.21 & 0.55 & \multirow[t]{4}{*}{$\mathrm{F}=0.112$} & \multirow[t]{4}{*}{0.896} \\
\hline 5-10 years & 4.11 & 0.48 & & \\
\hline $11-20$ years & 4.08 & 0.42 & & \\
\hline More than 20 years & 4.18 & 0.51 & & \\
\hline
\end{tabular}

Table 11 shows that statistical significance level is more than (0.05) and the calculated significance value (Sig) of demographic variables (gender, age, educational qualification, experience), is as follows (0.569), (0.296), (0.792), (0.896), respectively. Table results that there are no statistically significant differences in sample's subjects 'responses regarding strategic agility in Jordanian governmental organizations due to demographic variables. Therefore, the hypothesis is rejected which means that there are statistically significant differences between sample's subjects responses means regarding strategic agility practicing due to demographic variables.

The third main hypothesis: There are statistically significant differences between the means of respondents' responses regarding institutional performance excellence due to demographic variables (gender, age, years of experience, educational. level).

To verify this hypothesis, $t$ test was used for the two independent samples to test the differences due to gender variable, One Way Anova analysis was used to test the differences due to other variables that consist of more than two groups Table no. (12) Results of testing sample's subjects' responses differences regarding institutional performance excellence due to demographic variables.

Table 12. Shows the third main hypothesis test according to demographic variables

\begin{tabular}{lllll}
\hline demographic variables & Mean & S.D & T-test & Sig. \\
\hline Gender & & & & \\
\hline male & 3.85 & 0.41 & $\mathrm{~T}=0.246$ & 0.518 \\
\hline female & 3.68 & 0.43 & & \\
\hline Age & & & & 0.312 \\
\cline { 1 - 2 } Less than 30 & 485 & 0.51 & $\mathrm{~F}=0.612$ & \\
\hline 31- 40 years & 509 & 0.59 & & \\
\hline
\end{tabular}




\begin{tabular}{|c|c|c|c|c|}
\hline $41-50$ years & 4.21 & 0.46 & & \\
\hline More than 50 years & 4.41 & 0.53 & & \\
\hline \multicolumn{5}{|l|}{ Educational Level } \\
\hline high school & 4.18 & 0.42 & $\mathrm{~F}=0.476$ & 0.283 \\
\hline diploma & 4.14 & 0.48 & & \\
\hline bachelor's degree & 4.07 & 0.39 & & \\
\hline master's degree & 4.21 & 0.51 & & \\
\hline \multicolumn{5}{|l|}{ Experience } \\
\hline Less than 5 years & 4.32 & 0.52 & $\mathrm{~F}=0.432$ & 0.485 \\
\hline $5-10$ years & 4.54 & 0.41 & & \\
\hline $11-20$ years & 4.01 & 0.51 & & \\
\hline More than 20 years & 4.13 & 0.43 & & \\
\hline
\end{tabular}

Table 12 shows that statistical significance level is more than (0.05) and the calculated significance value (Sig) of demographic variables (gender, age, educational qualification, experience), is as follows $(0.518),(0.312),(0.283)$, (0.485), respectively. Table results that there are no statistically significant differences in sample's subjects 'responses regarding institutional performance excellence in Jordanian governmental organizations due to demographic variables. Therefore, the hypothesis is rejected which means that there are statistically significant differences between sample's subjects responses means regarding institutional performance excellence practicing due to demographic variable.

\section{Results and Recommendations}

First: the results

1. This study showed that there is a statistically significant impact of strategic agility determinants and dimensions of (strategic sensitivity, strategic goals selection, and clarity of vision, shared responsibility, core capabilities, and collective commitment) on organizational performance excellence in Jordanian government organizations

2. It was found through the results that the availability percent of strategic agility dimensions and limitations is high in Jordanian government organizations, and this consequently makes them able to adapt and deal with changes they face.

3. The study results showed that Jordanian government organizations have clear vision and mission for their future activities and they have clear goals known by all employees to achieve vision and mission. It was found that there is an integration and harmony in setting goals and work procedures among various Jordanian government organizations.

4. The study found that Jordanian government organizations do not care much regarding involvement of their employees in strategic planning process, nor are they keen to discuss differentiated ideas and do not encourage creativity and provide suggestions by organizations employees in these

5. This study indicated that top management in government organizations does not focus heavily on team working in one team spirit, nor does maintain their skilled employees.

6. It was found that government organizations, from respondents' perspective, do not consider their service beneficiaries views and do not deal with all stakeholders as liability partners.

7. The study found that there are no statistically significant differences between respondents' responses regarding strategic agility practicing and organizational performance excellence due to demographic variables (gender, age, years of experience, educational qualification).

8. The results indicated that Jordanian government organizations deal with new and advanced methods of providing services to citizens in medium form.

9. It was found through study results that Jordanian government organizations are seeking continuous improvement and constantly trying to develop their internal works according to ideal methods. They ales seek to obtain 
governmental excellence awards and they also provide their employees with appropriate training and education and have clear and fair appraisal methods for employee's performance.

10. The study results indicated that Jordanian government organizations do not follow clear and fair methods in appointing employees, nor do they seek to improve their employees invoke. Results also indicated that motives and bonuses are not distributed fairly to the differentiated employees.

Second: Recommendations

1. Jordanian government organizations have to increase their interest in all strategic agility dimensions and determinants due to their great role in achieving organizational performance excellence.

2. Government organizations should seek to achieve organizational excellence to increase interest in involving their employees in strategic planning process, discuss distinguished ideas, and encourage creativity and submitting proposals by their employees.

3. Team working with one team spirit is main pillar of organizational excellence, therefore it is necessary to increase interesting to and focus on this topic by top management in Jordanian organizations.

4. It is necessary to develop methods that Jordanian government organizations deal with, in particular, regarding electronic transformation of many services that are provided to beneficiaries according to best methods in this field.

5. Beneficiaries opinions are considered important issues that must be reviewed by Jordanian government organizations, in particular, regarding developing receiving complaints effective systems and listening to service recipient opinion and his suggestions to improve the provided services.

6. Jordanian government organizations have to increase their employees' interest, improve their income level and distribute bonuses fairly to distinguished ones., This will in its turn be reflected in employee's performance, since job satisfaction has a significant impact on performance excellence.

7. It is necessary to increase interest in retaining the current employees in these organizations, in particular the distinguished employees who have expertise, degrees and skills who are considered the main basis of organizational excellence.

8. Placing the right man in the right place is one of important basis for excellence. Therefore, Jordanian government organizations have to follow clear and fair methods in appointing employees, they should focus on efficiency and merit in recruitment process, not mediation and favoritism. This matter has to be clear appointment principle for both new employees. Or appointing department heads and managers in leadership positions in these organizations.

\section{References}

Abbas, Al-F. E. (2002). The impact of organizational learning processes and the characteristics of educated organizations on performance. Iraq: Karbala University.

Abbas, Al-R. S. (2005). Creating knowledge and job alienation and their effect on distinguished performance. Baghdad: Mustansiriya University.

Abdul-Razzaq, R. A. (2018). Leadership patterns and their impact on achieving strategic agility. Baghdad: Journal of Islamic Sciences, 20.

Abu Rady, S. (2013). Strategic Agility and Its Impact on the Operation Competitive Capabilities in Jordanian Private Hospitals. Unpublished Master Thesis, Jordan: Middle East University.

Ahmed, H. K. (2003). The role of performance management processes in distinguishing organizations, Iraq. Journal of Administration and Economics - Al-Mustansiriya University, 97.

Al-Azzawi, \& Al-Dabbagh. (2019). The effect of Organizational Agility on the Quality of Service. Baghdad Journal of Economic Sciences, (57).

Amro, \& Heba. (2016). Strategic Agility and its Relation to Competitive Advantage in Communications and Information Companies in Palestine. Unpublished Master Thesis, Palestine: University of Hebron.

Ashar, Al-K. S. Al-D. N. (2013). The effect of the principles of (OOAD) on the strategic agility: a field study in the number of Baghdad hospitals. Iraq: University of Baghdad.

Asma, A. (2001). The impact of the characteristics of the educated organization in achieving institutional distinction: an applied study in the Jordanian Ministry of Higher Education and Scientific Research. Jordan: Middle East University. 
Asmaa, I. (2018). Practicing Strategic Agility and Its Role in Improving Quality of Decisions in Non-governmental Organizations. Unpublished Master Thesis, Gaza: Al-Azhar University.

Doz, Y., \& Kosonen, M. (2008). Fast Strategy: How strategic agility will help to stay ahead of the game. Harlow: Wharton School Publishing.

Doz, Y., \& Kosonen, M. (2010). Embedding Strategic Agility: A Leadership agenda for Accelerating Business Model Renewal. Long Range Planning, 43(2). https://doi.org/10.1016/j.lrp.2009.07.006

Idris, W., \& Al-Rubaie, M. (2013). Examining the Impact of Strategic Learning on Strategic Agility. Journal of Management and Strategy, 4(2). https://doi.org/10.5430/jms.v4n2p70

Iman, Al-B. (2015). The relationship of administrative empowerment with work teams and its effect on achieving strategic agility, Iraq. Anbar University Journal for Economic and Administrative Sciences, 161-168.

Iman, Al-S. (2013). The Impact of Determinants of Strategic Active Agility and Regulatory: A Case Study of Lafarge Cement Company. Unpublished Master Thesis, Jordan: Middle East University.

Iman, M. (2010). Some requirements for agility and interdependence of knowledge-sharing tools, and the strategic dimensions of learning. PhD thesis, Iraq: University of Mosul.

Kamel, Al-H. (2019). Al-Azab, Hussein, The Mediating Effects of Dynamic Capabilities between Workforce Diversity and Strategic Agility in the United Nations Organizations Working in Jordan. Hussein Bin Talal University Journal for Research.

Lo, W.-S. (2017). Organizational Innovation into Process Reengineering: A Case Study of a Practical Training Hotel. The International Journal of Organizational Innovation, 9(1).

Majed, M. (2013). Strategic management: concepts, processes, and application cases (1st ed.). Jordan: Dar Al-Masirah.

Mohamed, Al-A. (2015). The importance of strategic intelligence in the decision-making process. Unpublished master's thesis, Algeria: Mohamed Khodeir University.

Muhammad, Al-H. (2015). The Impact of Strategic in the Light of the Competitive Capabilities of Companies on Operational Performance, a Study in Engineering Industries Companies in Jordan. Jordan: Middle East University.

Muhammad, H. (2016). Extent of Strategic Agility and its Relationship with Excellence in Institutional Performance in the Food Industries Sector in the Gaza Strip. Unpublished Master Thesis, Gaza University.

Nour, Al-Z. (2013). The effect of the characteristics of strategic information on achieving strategic agility and the role of strategic capabilities as a modified variable. Unpublished Master Thesis, Jordan: Middle East University.

Ojha, D. (2008). Impact of Strategic agility on competitive capabilities and financial performance. Unpublished PhD Thesis. Clemson University, USA.

Ruth, I. (2008). Interview with Mikko Kosonen and Yves Doz. Journal of Strategic Direction, 24(7). https://doi.org/10.1108/02580540810877401

Saltson, E., \& Ozgur, E. (2015). Impact of Workforce Diversity on a Business Organization. Nonfinancial Performance, with Moderation by Leadership Style and Perceived Organizational Support. International Journal of Economics, Commerce and Management, 3(5).

Tariq, R. (2014). The Impact of the Determinants of Strategic Agility on Organizational Excellence: An Empirical Study on the Communications Sector in Egypt, Tanta University. Journal of Finance and Trade, 3.

Wael, Al-G. T. I. (2007). Strategic Management from an Integrated Systematic Perspective, 1st Floor. Amman: Dar Wael for Publishing and Distribution.

\section{Copyrights}

Copyright for this article is retained by the author(s), with first publication rights granted to the journal.

This is an open-access article distributed under the terms and conditions of the Creative Commons Attribution license (http://creativecommons.org/licenses/by/4.0/). 